Nuclear war

\section{Other ways to reduce risks}

Washington

THERE is much that can be done to reduce the risks of nuclear war independently of high-level strategic negotiations between the superpowers, according to the American Association for the Advancement of Science committee on science, arms control and national security. At a congressional seminar held here last week, the committee suggested several possible courses of action, including developing better crisis control mechanisms, strengthening conventional military forces, "confidence building", avoiding provocative strategic policies and trying to reach agreement on the reduction of nuclear weapons.

Congress last year passed a nonbinding resolution calling for the establishment of nuclear risk-reduction centres. The feasibility of the centres was investigated by a group led by Senators Sam Nunn (Democrat, Georgia) and John Warner (Republican, Virginia) and used information from studies at Harvard, Stanford and Georgetown Universities in making specific recommendations. Last month, the Reagan administration formally agreed with the proposals and the concept was outlined to Mr Gorbachev by a group of senators who visited Moscow earlier this month. The Soviet reaction is reported to be "positive" and it is possible that the proposals will be included in the formal negotiations in November.

Nuclear risk reduction centres would maintain a 24-hour watch on events that might lead to a nuclear conflict and would be linked directly to relevant political and military authorities. One function of the centres would be to provide fast information about accidental or unauthorized launch of nuclear missiles, others would be the exchange of information about safety devices, joint planning during terrorist incidents, cooperation in any nuclear detonation by a third party and exchange of information about potentially threatening or misleading military activities, such as manoeuvres. The centres would not have a role in the resolution of "genuine" crises or in the negotiation of agreements, but would provide an institutionalized mechanism for a dialogue on how the United States and the Soviet Union perceive nuclear weapons risks independently of political negotiations. It is suggested that the centres be built in the two capital cities and linked via sophisticated real-time communications; there would be a liaison officer from each embassy. The centres, if established, would begin "modestly" with a narrowly defined function and would gradually evolve more complex roles; for example, a continuously updated database on nuclear forces could be maintained. Exactly how the centres would function and their res-

Nuclear winter ponsibilities await their appearance on the negotiation agenda.

The School of Government at Harvard University has produced an Agenda for Avoiding Nuclear War by lessening the chance of errors or accident. The proposals include the maintenance of a credible nuclear and conventional military deterrent, crisis management training for personnel involved in making decisions under pressure and establishing procedures for termination of crises. Many of these suggestions have been incorporated in a resolution passed recently by Congress, which requires a report on the proposals from the State Department by January 1986. A similar resolution requiring the
Department of Defense (DoD) to assess the suggestions is likely to be passed later this month.

Further specific recommendations made to congressmen include the establishment of an annual "risk of nuclear war" report, requiring DoD and other relevant agencies to assess the effects of new weapons systems not only on arms control but also on the broad array of factors that affect the risks of nuclear war. Others are more funding for intelligence collection and modernization of communications and sanctions against non-nuclear weapons states that try to acquire nuclear weapons without imposing adequate safeguards. Representatives of the committee on science, arms control and national security say they are pleased by the interest shown by congressmen in their proposals.

Maxine Clarke

\title{
Mechanics of SCOPE report
}

\section{Washington}

ThE Scientific Committee on Problems of the Environment (SCOPE) pulled no punches in presenting the principal conclusions of its report on environmental consequences of nuclear war in Washington last week.

The report, not yet formally published, is the product of a study launched in June 1982. The work has been carried out by a series of workshops, involving more than 300 physical scientists and biologists, and organized by a steering committee directed by Sir Frederick Warner and based at the University of Essex.

Mark Harwell of Cornell University, a principal author of the section of the report dealing with biological effects, said the key conclusion was that the indirect effects of a plausible nuclear war, principally starvation due to crop failures, might kill up to 4,000 million people, besides the several hundred millions who might die from direct effects. He invoked mass starvation in Ethiopia and the Sudan as more appropriate images of the aftermath of nuclear war than Hiroshima and Nagasaki, and estimated that more might die in a non-combatant nation such as India than in the Soviet Union and the United States put together

Although the SCOPE report does not address policy questions, the SCOPE steering committee makes no secret of its wish that policy lessons be drawn from it. Sir Frederick Warner said that "anybody who thinks they can read this and not draw policy conclusions is making a big mistake".

Through SCOPE's parent body, the International Council of Scientific Unions (ICSU), efforts are being made to ensure that the striking conclusions from the new study are conveyed to the highest levels of government. The Prime Minister of India. Rajiv Gandhi, is already known to have a special interest in the subject, and the report has been directed as well to officials in the governments of Australia, the United States, the Soviet Union and Britain.

The US Secretary of Defense, Caspar Weinberger, has said little on the subject of "nuclear winter", the usual name for large-scale cooling effects following a nuclear war. But an internal State Department memorandum to Secretary of State George Schulz dated 16 August 1984 says that "the implications for US policy of the nuclear winter theory as it is being argued by Turco, Toon, Ackerman, Pollack and Sagan (in Science 222, 1283; 1983) could be profound if the administrationsponsored studies agree with Turco et al.'s conclusions and/or if, by default, congressional and public attitudes are moulded by those results".

The US National Academy of Sciences study on the subject, published at the end of 1984 , supported the "clear possibility" that the climatic consequences of a nuclear war might include a severe cooling of the kind described.

For last week's launching, SCOPE took the unusual step of hiring a public relations organization, the Center for the Consequences of Nuclear War, to publicize the report to the Washington press. The report will be formally published later this year, and a final version is nearing completion with support from private US foundations. ICSU has established a group to look at the conclusions and decide what research should be done next.

Some of the report's authors urged the audience at a scientific presentation of the results last week to use the report to oppose the use of nuclear weapons. And a Japanese SCOPE delegate, Yasuo Shimazu of Nagoya University, circulated an impassioned plea to delegates urging them to take active steps to prevent nuclear war from starting.
Tim Beardsley 